\title{
A SUCCINCT ANALYSIS OF MITIGATING LIQUIDITY RISK IN ISLAMIC BANKS IN THE LIGHT OF LIQUIDITY AND RISK MANAGEMENT PRINCIPLES
}

\author{
Naeem Suleman Dhiraj ${ }^{1 *}$, Atharyanshah Puneri ${ }^{2}$, Hafiz Benraheem ${ }^{3}$ \\ *Corresponding author: \\ ${ }^{1}$ Institute of Islamic Banking and Finance, International Islamic University Malaysia. dhirajnaeem@gmail.com \\ ${ }^{2}$ Institute of Islamic Banking and Finance, International Islamic University Malaysia. athpun@gmail.com \\ ${ }^{3}$ Institute of Islamic Banking and Finance, International Islamic University Malaysia. hhbenraheem@gmail.com
}

\begin{abstract}
Liquidity management has been incessantly challenging for the financial institutions and especially Islamic financial institutions due to their nature of business. The convoluted nature of liquidity management impedes the task of Islamic banks in managing their liquidity efficiently. Given the intricacies of the subject matter, this paper delves into elaborating the critical aspects of liquidity management; subsequently, discusses the consequences of poor liquidity management and problems inherent in managing the latter by analyzing the real-life failure of an Islamic financial institution as a result identifying the issues that could possibly jeopardize the existence of the Islamic banks. The research aims to provide a comprehensive understanding of the liquidity management framework and furnish with effective tools to mitigate the liquidity risk for the Islamic banks.
\end{abstract}

Keywords: liquidity management, risk management, islamic bank, financial market, basel III framework

\section{INTRODUCTION}

Nowadays, Islamic finance is growing actively and rapidly in the global financial system. According to Islamic Financial Services Industry Stability Report by The Islamic Services Board (IFSB), the global Islamic financial services industry (IFSI) firmly grew with $8.3 \%$ in the asset, and its total worth was around USD 2 trillion in 2017 (IFSB, 2018). More importantly, Islamic finance is not confined to only Muslim countries; it spread in many jurisdictions in which the Muslim community is located (Kasi \& Muhammad, 2018). Islamic banks, as a representative of the majority of Islamic financial institutions (IFIs), are spread locally and internationally across both Muslim and non-Muslim countries. The emergence of Islamic banking is due to the increasing demand from Muslim communities worldwide for Shari' 'âh complied Islamic financial products, services, and the variety of modes of Islamic finance. Since banks are more leveraged entities compared to other businesses, liquidity is much more essential (Bello, Hasan, \& Saiti, 2017). According to Sulaiman, Mohamad, and Samsudin (2013), Basel Committee has defined liquidity as a bank's capability to fund an increase in assets and meet obligations as they come due, without incurring unacceptable losses. Therefore, liquidity management refers to the ability of banks for matching the maturity of assets and liabilities daily and coping with short-term pressures that may arise in the process of ensuring that the assets are fully funded (Ayub, 2017).

For Islamic banks, liquidity management is unique and requires sophisticated liquidity risk mitigating criteria to avoid any financially distressful situation. More often than not, financial institutions liquidate their assets and pay the depositors their capital, and after that, the regulators force them to cease their operations. Islamic banks are no exception. 
Such potential legal hazard necessitates proactive measures for efficient management of the liquidity flow. For these reasons, the research aims to provide a succinct discussion on liquidity and risk management for the Islamic banks. It begins with an extensive literature review discussing various Shari'äh-compliant instruments for liquidity flow in the Islamic Interbank Money Market (IIMM). Furthermore, the research provides a detailed discussion on the role of the IIMM that helps keep the short-term liquidity requirement of the Islamic banks afloat. It expounds on the risk management principles to be deployed for efficient management of the liquidity. After that, the paper embarks on analyzing one of the finance houses that was forced to cease its operations due to the poor liquidity management and as a result bases the logical reasons as to the consequences of poor liquidity management and its avoidance. Finally, it deliberates on the measures to be taken to manage the liquidity risk for the Islamic banks effectively.

\section{LITERATURE REVIEW}

\section{Challenges in developing Shari'āh-compliant IIMM instruments}

Many works of literature deliberate on liquidity management for Islamic banks. Abdul Rais and Abdul Majid (2003) believes that the infrastructure and the tools for liquidity risk management in Islamic banks are still inadequate, which limits the development of the Islamic interbank money market (IIMM). Similarly, Ismal (2010) suggests that Islamic banks should develop a comprehensive organizational structure to devise liquidity instruments to meet the ordinary and extraordinary liquidity needs. Shehu and Rano (2015) expound that Islamic banks face several challenges in managing their liquidity, especially in the short-term. Further noticing the lack of a developed money market and especially an interbank money market. Lahsen and Elouali (2018) state that Islamic banks are facing difficulties in developing Islamic financial instruments to tackle short-term liquidity requirements. Furthermore, the study from Onal (2016) shows that Islamic liquidity management faces some Shari'āh related challenges especially in the sense of the need to find a generally accepted Islamic structure both for the underlying sovereign asset pool and future short-term sukuk. This is in addition to two types of technical challenges; 1) Shari' $\bar{a} h$ issues in the financing of high-quality sovereign assets to obtain high ratings; 2) Shari' $\bar{a} h$ issues in managing the duration mismatch between short-term liability and long-term assets in a Shari'äh-complaint way. Ariffin (2012) finds that the level of liquidity risk reporting is still at a minimum. The disclosure of firms' risk-management positions and strategies is crucial to improve corporate transparency for market participants and to enhance corporate governance. Particularly on the liquidity risk management disclosure, it is important for the standard-setters and the bank regulators to work together to improve the risk disclosures, including liquidity risk. Rizkiah (2018) deliberates mainly on liquidity management issues and challenges in Islamic banking and discovers the limited availability of the liquidity management instruments for Islamic banks. In addition to that, the rapid evolution of the Islamic banking business requires amendments and innovation in the prevailing liquidity management instruments especially the inactivity of its secondary market, key issues on short term issuance, and difficulty of cross-border transactions. 


\section{Jurisdictional constraints}

Song and Oosthuizen (2014) states that Islamic banks are usually forced to maintain higher liquidity than conventional banks in view of the dearth of investment opportunities with a short- term tenure that offers the prospect of a return. The lack of liquidity facilities with the monetary authority is also a challenge for Islamic banks. Although Islamic banks have access to the available liquidity facilities, the Shari'a $h$ requirements forbid the Islamic banks from resorting to the conventional liquidity management instruments. Therefore, central banks in some jurisdictions where Shari' $\bar{a} h$ law is not part of the fundamental law of the country, make specific provision for Shari 'āh-compliant liquidity facilities for Islamic banks. In jurisdictions where Islamic banks are part of the financial system, central banks in those jurisdictions should consider catering for the special needs of the Islamic banks in the context of lender of last resort or emergency lending arrangements by providing Shari'āh-compliant arrangements. Also, supervisory authorities and audit firms should ensure to monitor banks' effective liquidity risk management in the context of ascertaining liquid assets, longer-term funding, using Shari'āh-compliant liquidity hedging instruments, and interbank market instruments. While the Islamic banks are required to use the Shari' $\bar{a} h$-complaint liquidity instruments, the Islamic windows are deprived of an avenue to use Shari'āh-complaint liquidity instruments, hence, the conventional parent organization of the Islamic window ends-up using the conventional liquidity management instruments. This is rightly pointed out by Bello, Hasan, and Saiti (2017) in their study stating that there are many instruments innovated to cater for liquidity risk for the Islamic banks, but the main concern is that they lack global acceptability, which in turn, limits their tradability, adaptability, and flexibility. Further, they mention that the majority of the assets held by the Islamic banks are illiquid while their liabilities are relatively liquid, which is the major source of asset-liability mismatch in their balance sheets. However, this does not mean that conventional banks are immune to liquidity risk; rather the point here is that the Islamic banks are more vulnerable to liquidity risk.

\section{Governance mechanisms}

Furthermore, research shows that the liquidity risk of Islamic banks has been growing since 2004 due to the contractual form of instruments, Shari'āh restrictions on certain contracts, and financial infrastructure deficiency. Rashid, Rahman, and Markom (2018) notes that not only the governance aspect is crucial in a comprehensive effort to ensure the success of the industry, but also the information disclosure is necessary as an approach within the governance scope of authority to maintain the trust and consumer interest. The financial holding company is required to make public disclosure of information, including those which were previously considered confidential. Additionally, a supervisor must be equipped with adequate knowledge related to the challenges of Islamic financial products and the impact of the interaction between conventional and Islamic banking. The supervisory authority must also be sensitive and be aware of the possibility of regulatory arbitrage between conventional banks and Islamic banks. Subsequently, regular and structured supervisions which are necessary while monitoring some of the strategies in the supervising process. This shows that the specific supervision process is required to manage liquidity risk in Islamic banking. 


\section{Causes of the liquidity crisis}

According to Jedidia and Hamza (2014), liquidity risk can arise if there is a late or nonpayment of profit payment during the contract. It can also be related to the nonpayment by the client of the principal at the end of the contract. However, Mushārakāh and mudarabah have a problem with periodic evaluation of these long-term assets. The absence of a secondary market for these products leads to their costly evaluation. In liabilities, the liquidity risk emerges if the bank is not able to satisfy the liquidity behavior of its depositors for both routine liquidity demand and liquidity distress demand. The study of liquidity management of Islamic bank in Nigeria from Shehu and Rano (2015) shows that the bank is barred from operating in the interbank transactions with other conventional banks. Coupled with lack of Shari'äh-compliant investment instruments, the Bank, all things being equal, is expected to have excess liquidity, which is safer but delivers lower profit. Contractual risks leading to liquidity problems can be managed by careful documentation, parallel contracts, and securitization of the underlying assets particularly in the cases of ijarah, salam, and istisna' while seeking out the avenue of its trading in the secondary market where possible (Ayub, 2017).

\section{Variance in Juristic opinions}

Furthermore, Abdullah (2010) states several challenges to liquidity management in Islamic banks. First and foremost, establishing a globally accepted Shari' āh-compliant liquidity management scheme is a real challenge. The differing interpretations of Shari'āh rulings, i.e., fatwa, on financial matters across jurisdictions have led to differing methods of structuring or packaging financial instruments, and to the non-validity or non-recognition of some contracts or terms of practice in certain jurisdictions, which could prove to impede a global scheme. Second, in the absence of an adequate cross-border liquidity market and infrastructure, Islamic banking institutions will have poor cash management arising from the lack of a comprehensive Islamic interbank market with highly rated short-term tradable instruments. Without access to such a market, it is difficult for these institutions to manage their short-term liquidity needs efficiently and effectively. Furthermore, short-term financial instruments are the availability of Shari'äh-compliant money market instruments because this is still quite limited and varies from country to country. Thirdly, in some countries, the regulatory liquidity requirements for Islamic financial institutions (IFSs) are less stringent than conventional banks. This is due to the limited availability of liquid Shari'āh-compliant instruments.

\section{THE ROLE OF ISLAMIC INTERBANK MONEY MARKET (IIMM)}

Unlike the Islamic capital market, which serves as a platform for issuing and trading of long-term securities, Islamic money market provides an avenue for liquidity management and secondary trading of money market instruments. More importantly, this avenue is utilized by the central bank to conduct monetary policies (Muhammad \& Ahmed, 2016). Islamic Money Market is one of the significant components of the Islamic financial system. The diagram illustrated below provides a general overview of the various components of the financial market to further comprehend the modus operandi of Islamic interbank money market (IIMM). 


\section{Overview of Islamic finance ecosystem}

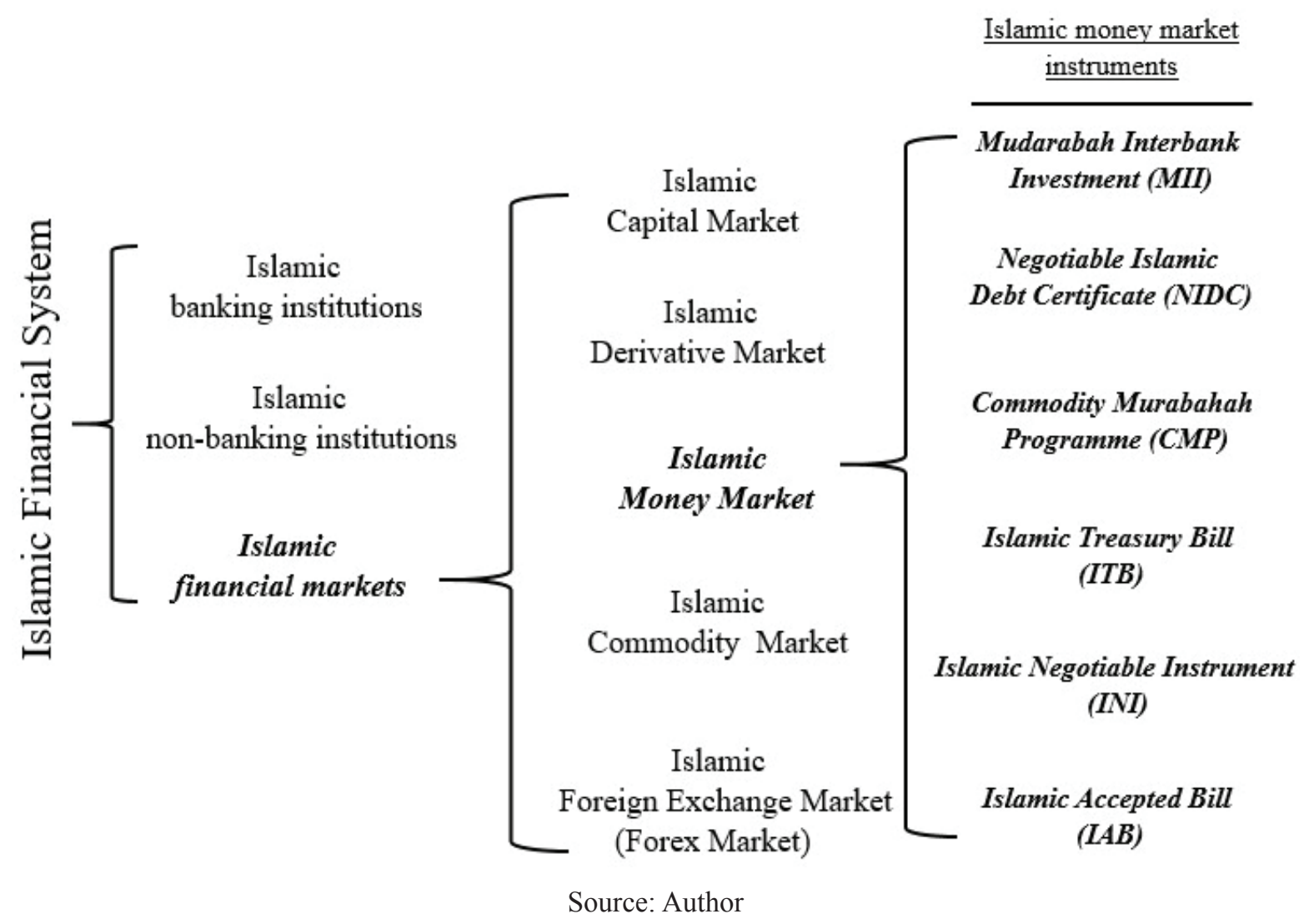

Figure 1: Islamic financial markets and IIMM instruments

Islamic financial markets consist of other market segments that facilitate the unique needs of the Islamic financial institutions. Among various components of the Islamic financial markets, the Islamic money market is a driving agent that facilitates with a broad spectrum of Islamic financial instruments such as shown in the figure above. Effective and efficient liquidity management has always been enigmatic in nature for the management, posing a severe threat to the existence of the Islamic banking institution. To overcome this challenge, the Islamic money market assists the Islamic banking institutions in mitigating the liquidity management problem while also enabling them to alleviate the asset-liability mismatches. There are various Islamic financial instruments rolled out in the IIMM, such as depicted in the figure above.

Among many financial instruments available, Commodity Murabahah Programme (CMP), which is also known as Commodity Murabahah liquidity facility is the one widely practiced among the IFIs in IIMM to satisfy their liquidity requirement. This arrangement is primarily based on Tawarruq, which is commonly practiced by the IFIs to obtain shortterm interbank liquidity. Such arrangement takes place between two IFIs in IIMM wherein the investing bank (the bank that gives financing) purchases an asset from a broker (i.e., broker A) and sells it to the investee bank (bank in need of financing) at deferred payments. Since the intention was not to acquire the asset, rather cash, the investee bank may choose to appoint the investing bank to act as its agent to sell the asset to another broker (i.e., broker B) or may choose to sell itself as a result acquiring cash. This reverse phenomenon is termed as reverse Tawarruq. 
Amidst emerging liquidity challenges and Islamic banks facing difficulties in maintaining asset- liability balance, the International Islamic Liquidity Management (IILM) Corporation was established in 2010 to facilitate cross-border liquidity management to its member countries. IILM is a consortium of central banks from nine countries, including the private arm of the Islamic Development Bank. Its primary function is to leverage member countries' IFIs with providing liquidity by issuing short-term Shari'āh-compliant Islamic securities (IILM, n.d.).

As evidently apparent, the role of the Islamic money market is crucial in providing cushion to the Islamic banks for effectively managing their liquidity requirements. In the absence of this vital organ of the financial market, the entire Islamic banking system would come to a halt.

\section{Liquidity Management General Ideas}

Liquidity management in the banking sector can be defined as an activity of a bank in which a bank ensures that its liquid assets are sufficient enough to meet the obligations as they become due (Casu, Girardone, \& Molyneux, 2006). Liquidity management includes forecasting, managing cash flows and position, and includes setting a strategy towards a preferred cash position or liquidity target (Zietlow \& Seidner, 2007). Liquidity management is the ability to meet financial obligation at a reasonable cost. Liquidity management, therefore, involves strategic supply or withdrawal from market or circulation the amount of liquidity consistent with the desired level of short-term reserve money without distorting the profit-making ability and operations of the bank. (Ogbada \& Osuji, 2013)

\section{Importance of Liquidity Management for Islamic Banks}

Problem with insufficient liquidity can lead not only to the collapse of a specific Islamic bank but also lead to the instability of the entire financial system of a country (Llewellyn, 1999). The Basel Committee mandated the liquidity management framework as the element of the Basel III framework (Hartlage, 2012). On the one hand, insufficient liquidity can lead the bank into a catastrophe, but on the other hand, excessive liquidity undermines the profit potential of the bank. Excessive liquidity in a bank can harm competitiveness. Liquidity management is, therefore, critical for all banks, including Islamic banks (Sobol, 2013).

\section{CONSEQUENCES OF POOR LIQUIDITY MANAGEMENT Why Banks Face Liquidity Problems?}

As mentioned earlier, liquidity management is paramount for banking institutions. Poor liquidity management leads to financial distress, including banks facing bankruptcy. Liquidity for Islamic banks is managed differently compared to conventional banks. However, in general, the core objective of the liquidity management for the bank is to ensure that the bank is able to meet the future obligations of funding commitments and deposit withdrawals without any difficulties (Bank Islam, Directors' report, December 2017, pp. 93). Among many other reasons, liquidity problem occurs primarily due to the imbalances between the maturity dates of the assets and the liabilities (Slide player, n.d.). This is true regardless of the bank whether it is Islamic or conventional except that for Islamic banks the "Profit and loss sharing on the 
liability side and a portfolio mix of profit and loss sharing and fixed mark-up contracts on the asset side [...] [makes Islamic banks] more stable entity than a conventional bank in which deposits constitute capital [which is] certain fixed liability while the asset side is [sic] value [is] uncertain" (Ali, 2007, p.4).

A bank's financial health is determined by calculating various financial ratios. In particular, the quick ratio can aid in interpreting the liquidity aspect of the bank. In essence, this ratio demonstrates whether a company is able to use its near cash assets or the most liquid assets to get rid of its current liabilities instantly if required. This serves as an emergency exit in times of financial distress.

\section{The Failure of Ihlas Finans}

Ihlas Finans was among the most prominent Specialized Finance Houses (SFHs) in Turkey. In the wake of the global financial crisis of 2000 and 2001, where many Islamic financial institutions survived across the world, many however collapsed and Ihlas Finans was one of those that could not sail through the financial Tsunami and eventually sank. What is essential here is to determine what caused the failure of Ihlas Finance? Being an entity based on Islamic finance principles, by nature, it is well protected in terms of its liabilities since unlike conventional banks the Islamic banks and especially the Islamic finance houses given their nature of business have the luxury of having prolonged holdings of the capital from investors until maturity. Ihlas Finans collapsed in 2001, whereby its license was canceled by Banking Regulation and Supervision Agency (BRSA) (Ali, 2007). A case study conducted by Ali (2007) states that poor liquidity management was a massive contributor among numerous other reasons associated with Ihlas Finans' collapse. It further indicates that the percentage of liquid assets to total assets was $4.22 \%$ in 1999 , which further diminished to $0.53 \%$ in $200 \mathrm{o}$, and finally plummeted to $0.013 \%$ in 2001 .

\begin{tabular}{llccc}
\hline \multicolumn{1}{c}{$(0)$} & $(1)$ & $(2)$ & $(3)$ & $(4)$ \\
& & $31 / 12 / 1999$ & $31 / 12 / 2000$ & $10 / 2 / 2001$ \\
\hline Ratio of & IFH & $4.22 \%$ & $0.53 \%$ & $0.27 \%$ \\
Liquid Asset & & $0.55 \%$ & $0.03 \%$ & $0.013 \%$ \\
to Total & \multirow{2}{*}{ KTEFH } & $11.01 \%$ & $10.39 \%$ & - \\
Assets & & $1.02 \%$ & $1.4 \%$ & \\
& & $15.8 \%$ & $7.5 \%$ & - \\
& AFH & $1.48 \%$ & $1.3 \%$ & \\
\hline
\end{tabular}

Notes: 1 . The first ratio is (cash + cash with banks + reserves)/total assets, the second ratio is cash to assets.

(Source: Ali, 2007)

Table 1: Liquidity ratio of Ihlas Finans

The last global financial crisis emerged as a Tsunami and systemic in nature that engulfed the entire financial and monetary systems of many countries. Due to this effect, not surprisingly, the cash kept by Ihlas Finans with other banks including Central bank was lost and as a result, it could not pay its depositors since it also experienced a run on its business. 


\section{RISK MANAGEMENT General Ideas}

There is no clear definition of risk. Many definitions define risk. Even the meaning of risk can be changed over time and places. However, in order to try to make it clear, risk can be defined as the combination of the probability of an event and the consequences that comes with it. Risk also refers to future issues that could be avoided, or it also can be the probability of something to happen (Knight, 1921). All in all, risk can be defined as the combination of the likelihood of a hazardous event occurring with the possible accompanying loss or unwanted consequences. (Hubbard, 2007)

Risk also being recognized in the banking world. Both if Islamic and Conventional Banks are exposed to some risk. However, because of the difference in form and substance of banking activities between Islamic Banks and Conventional banks, it caused some differences in risk profile for Islamic Banking.

According to Reyazat (2012), Islamic banks also have unique risks, which are as follows:

1) Shari' 'ăh non-compliant risk: Risk that arise from the failure to comply with Shari'āh rules and principles

2) Rate of Return Risk: The potential risk that can arise on the return caused by an unexpected change in the rate of returns.

3) Displaced Commercial Risk: The risk that the bank may confront commercial pressure to pay returns that exceed the rate that has been earned on its assets financed by the investment account holder

4) Equity Investment Risk: The risk that arises from entering into a partnership to undertake or participate in a special financing or general business activity as described in the contract. This risk is relevant to mudārabāh and Mushārakāhh contract.

According to the study conducted by Rosman et al. (2017), out of four unique risks that are mentioned above, Shari' $\bar{a} h$ non-compliance risk is the most critical one. It highlights possible failure to meet the obligations or satisfy the Shari'äh principle as prescribed in the relevant jurisdiction's set of standards. Moreover, managing this risk is very important for Islamic Banks because if an Islamic bank fails to comply with the Shari'āh standards, it will have an impact on its reputation and sustainability.

As for risk management, it has many definitions, most of which are broad in terms (Williams et al., 2006). A study conducted by Taher (2004) defines risk management as an integrated process to control the risk and reduce the size of loss using the best means and lowest cost by identifying, analyzing and assessing risks. It also includes identifying the means to address risk by selecting the best tools to achieve the desired goals. Taher (2004) on the other study that conducted by Khalid and Amjad, they agree with Taher's definition of risk management and further enhancing it by adding 2 steps conducted in every risk management practice, which are: 1) identifying the origin and causes of risk, and 2) developing ways to assess risks using mathematical models (Khalid \& Amjad, 2012). 


\section{Importance of Risk Management}

No one can ignore the importance of risk management practices, especially in banking. Many incidents happen because of the lack of risk management practices, one of them is the "Black Monday" incident in the US around the 1980s, where that incident was hit US capital market and reminds all the investor of the inherent risk and volatility in the market. There are three contributing factors to the importance of risk management, which are:

(1) Regulation of financial institutions. Where deregulation, globalization, and disintermediation have led to the changes in the markets and the economics that are operating within the market. These things made financial risk management practices more critical (Penza \& Bansal, 2001).

(2) The rapid changing in technologies. The current rapid changes in technologies, where it change from physical to computing programs were led to an important innovation in financing world and also introducing new risk that emerges such as online risk (Johnson, 2000). The rapid changes in technologies also led to the rapid changing of risk exposure and increase in financial innovations and advances in economic theory.

\section{Risk Management Framework}

According to Froot, Stein, and Scharftein (1994), there are three pillars of risk management framework as given below:

- First Pillar: To make a sound investment decision to create corporate value

- Second Pillar: To generate enough cash flows internally as this is the key to making suitable investments.

- Third Pillar: A company's ability to invest can be jeopardized if cash flow is disrupted by adverse movements in external factors such as interest rates, exchange rates, and commodity prices

Therefore, risk management programs' primary objective should be to ensure that the bank has the cash available to make value-enhancing investments.

According to the Basel Committee on Banking Supervision (BCBS) in 2001, the Basel Committee on Banking Supervision (BCBS) defines that there are four essential elements in risk management frameworks, which are:

- The identification of the risk

- The assessment of the risk using data and risk model

- The monitoring and of the risk assessment on a timely basis

- Control of these risk by senior management

Thus, according to the elements above, it was believed that the risk management framework is a proactive, systematic analysis of possible events and responses to them rather than a mere reaction mechanism to those limited events that are detected. It is about managing the future rather than administering past events. (OECD, 2001)

There are four major risk management factors, as described below:

(1) Risk Identification

First, it is to identify risks to understand the types of risks and the sources of risks, the complexities of risk, and the potential issues that may impact the bank from the risk 
concerned. Secondly is to identify the risk concentrations and determine whether the significant risks are due to the size or nature of the position. Risk identification process also includes a risk-ranking component. These rankings are usually based on impact, severity, or dollar effects (Barton, Shenkir, \& Walker, 2002).

(2) Risk Measurement

Risk measurement process covers the utilization of the appropriate risk indicators to measure the size of risk and its impact on the bank and its business activities. According to the study that conducted by James (1996), many innovations in the method and system of measuring risk are motivated by the ability of the bank to allocate capital among their expanding array of non-traditional, fee-based activities.

(3) Risk Mitigation

Usually, the risk is prioritized and then determined whether the risk should be accepted, transferred, mitigated, or eliminated. The traditional move of accepting and transferring the risk is by means of insuring the risk. However, for risk that could not be transferred, the next step would be to mitigate or try to reduce it through risk mitigation tools and techniques. Elimination of risk is not possible for inherent risks.

(4) Risk Control, Monitoring, and Reporting

The process of risk monitoring includes compliance with the existing risk management policies and limits to create a more robust control environment. It also involves extensive monitoring and reporting within the risk management policies and limits, to the authorities for the appropriate decision making.

\section{Management of Liquidity Risk}

In conventional banks, banks with long-term commitments and short-term resources will generate immediate and future deficits. Future deficits require raising funds as rates are unknown today. Future expenses of funds require investing in the future. Hence, liquidity risk triggers interest rates because future funding and investment contract have unknown rates unless ALM sets up hedges. According to Bessis (2002), liquidity risk in conventional banks is usually being managed by the Asset and Liability Management Committee (ALCO). This committee is responsible for both statutory and prudential risk.

As for Islamic banks, liquidity risk will arise when there is insufficient funds or resources to meet with customers' demands. A study conducted by Iqbal and Mirakhor (2007) finds some significant improvement taking place in Islamic Banks in order for them to manage and mitigate the liquidity risk. One of the substantial improvements is the introduction of Sukuk and Shari'āh compatible securities which might act as a catalyst for the secondary market and later provide liquidity. Another improvement is the establishment of the International Islamic Financial Market, as the establishment of Islamic Inter-Bank Money Market (IIMM) in Malaysia, for efficient liquidity needs of the Islamic Banks. 


\section{MEASURES TO MITIGATE LIQUIDITY RISK Diversification}

Portfolio diversification is a vital tool in mitigating liquidity risk on a condition that the assets pooled in the portfolio are negatively related to each other. If they are positively related, the bulk of assets will perform identically. Meaning, if the market is in a downturn, none of the assets in the portfolio will complement other to balance the risk. This portfolio will turn out to be futile. As such, utmost care should be taken during portfolio creation to have diversified assets to mitigate liquidity risk.

\section{Forecasting Cash Flows}

According to Scholes (n.d), cash flow forecasting is paramount in that it provides a transparent image of the financial institution and acts as a guarding shield against the liquidity risk. Periodic audits of the forecasted cash flows allow the management to decipher the anomalies and variances that may hinder the bank's ability to cope with the distressing financial situation in the time of immediate liquidation. It must be emphasized that the individuals involved in monitoring cash flows must have up to date information to prevent the bank from falling into the pit of the liquidity crisis.

\section{BASEL III Liquidity Requirements}

The Basel Committee on Banking Supervision (BCBS), an international organization that oversees the international banks operations, has stipulated stringent liquidity requirement standards for the banks in its newly proposed Basel III framework in response to the 2008 financial crisis. It primarily focuses on Liquidity Coverage Ratio (LCR) and Net Stable Funding Ratio (NSFR) in terms of mitigating the ongoing liquidity crisis issue within the banks. According to Adel (n.d), by incorporating these liquidity measuring ratios, BCBS is aiming to achieve two complementary objectives. First, strengthening banks' short-term liquidity profile. This means that the international banks will be required to maintain a certain level of liquidity so that it can cover short-term funding gaps, which is under 30 days. Second, to strengthen banks' medium to long term liquidity profile. The exposure draft of Bank Negara Malaysia (BNM) for example, sets out its proposal in accordance to Basel III regulatory reform stating that, "Net Stable Funding Ratio (NSFR) is a minimum standard that requires banks to maintain a stable funding profile in relation to the composition of their assets and off-balance sheet activities." (Bank Negara Malaysia Exposure draft, 2017). This, in turn, suggests that Islamic banks'(IBs) strict adherence to the Basel III requirements will further help them achieve optimal liquidity safety net.

\section{CONCLUSION}

To summarize, liquidity management and risk management are vital tools for Islamic financial institutions. Undermining the potential of these tools is similar to inviting misfortune for the Islamic banks. Hitherto, the Islamic banks faced unprecedented challenges in the management of liquidity and risk in which the latter serves as the precursor to the former. The techniques discussed earlier, if deployed prudently, will assist the Islamic banks in mitigating 
liquidity risk to a substantial level. As seen in the case of Ihlas Finans house, it is paramount to maintain the liquid asset ratio to the total asset ratio. Although it is understood that the run on a business is unanticipated and unilateral to the Islamic banks, it is, however, critical for the Islamic banks to remain extra-vigilant of their liquidity requirements since the Islamic banks are more vulnerable to liquidity crisis than its conventional counterpart.

\section{REFERENCES}

Al Zararee, A. N., \& Al Faris, J. (2014, April). The Efficiency of Liquidity Management in Islamic Banks(Conservative vs. Profit). International Journal of Business and Social Science, 5(5).

Bank Negara Malaysia Exposure draft. (2017, September 27). Retrieved November 28, 2018, from http://www.bnm.gov.my/index.php?ch=57\&pg=137\&ac=620\&bb=file

Barton, T., Shenkir, W. G., \& Walker, P. L. (2002). Making Enterprise Risk Management Pay Off. USA: Prentince Hall PTR/ FInancial Times.

Basel Committee on Banking Supervision (BCBS). (2001). Consultative Document: Operational Risk. Basel: Basel Committee on Banking Supervision.

Bessis, J. (2002). Risk Management in Banking. England: John Wiley \& Sons, Inc.

Casu, B., Girardone, C., \& Molyneux, P. (2006). Introduction to Banking. USA: Prentice Hall Financial times.

Froot, K., Stein, J., \& Scharftein, D. S. (1994). A Framework for Risk Management. Harvard Business Review, 91-102.

Hartlage, A. W. (2012). The Basel III Liquidity Coverage Ratio and Financial Stability. Michigan Law Review.

Hubbard, D. W. (2007). How to Measure Anything, Finding the Value of Intangibles in Business. New Jersey: John Wiley \& Son.

IILM. (n.d.). Retrieved November 26, 2018, from International Islamic Liquidity Management (IILM) Coporation: http://www.iilm.com/about-us/

Iqbal, Z., \& Mirakhor, A. (2007). An Introduction to Islamic Finance: Theory and Practice. Singapore: John Wiley and Sons Asia, Pte, Ltd.

James, C. (1996). RAROC Based Capital Budgeting and Performance Evaluation: A Case Study of Bank Capital Allocation. Wharton's Financial Institutions Center's Conference on Risk Management in Banking. Pennsylvania: Wharton Financial Institution Center.

Johnson, P. (2000). Value at Risk: The New Benchmark for Managing Financial Risk. Singapore: John Wiley \& Sons Asia, Pte, Ltd.

Khalid, S., \& Amjad, S. (2012). Risk Management Practices in Islamic Banks of Pakistan. The Journal of Risk Finance, 13(2), 148-159. 
Knight, F. H. (1921). Risk, Uncertainty and Profit. Chicago: Houghton Miffin Company.

Llewellyn, D. (1999). The Economic Rationale for Financial Regulation. Ocassional Paper Series.

Muhammad, M., \& Ahmed, U. M. (2016). In Islamic Financial System: Principles and Operations, 2nd Ed (p. 152). Kuala Lumpur, Malaysia: International Shari'āh Research Academy for Islamic Finance (ISRA).

OECD. (2001). Risk Management-Practice Note. Paris: OECD.

Ogbada, A. O., \& Osuji, C. C. (2013). The Efficiency of Liquidity Management and Banking Performance in Nigeria. International Review of Management and Business Research, 2(1), 223-233.

Penza, P., \& Bansal, V. K. (2001). Measuring Market risk With Value at Risk. New Jersey: John Wiley \& Sons, Inc.

Reyazat, F. (2012). Risk Management Framework in Islamic Banking: Basel II and Basel III, Challenges and Implications in Islamic Banking. Money and Economy, 6(2), 69-122.

Rosman, R., Azmi, A. C., \& Amin, S. N. (2017). Disclosure of Shari'āh Non-Compliance Income by Islamic Banks in Malaysia and Bahrain. International Journal of Business and Society, 18, 45-58.

Slideplayer. (n.d.). Retrieved November 27, 2018, from https://slideplayer.com/slide/11767601/

Sobol, I. (2013). Liquidity Management Practices in Islamic Banking. 566-577.

Taher, M. (2004). Modern Risk Management in Banking and Finance. Beirut: Union of Arab Banks.

Williams, R., Bertsch, B., van der Wiele, T., van Iwaarden, J., Smith, M., \& Visser, R. (2006). Quality and Risk Managemet: What Are the Key Issues? The TQM Magazine, 18(1), 67-86.

Zietlow, J., \& Seidner, A. (2007). Cash \& Investment Management for Non-profit Organizations. New Jersey: John Willey \& Sons, Inc. 